Економічні науки: збірник наукових прачь Луиького національного технічного університету. Серія "Регіональна економіка". Випуск 17 (67). Редкол.: відп. ред. к.е.н., професор І.В. Кривов’язюк. Луцьк: ІВВ Луцького НТУ, 2020. 348 с.

Dr Grzegorz Zając

Assistant Professor, Deputy Director of the Institute of Safety and Health Sciences

Old Polish University in Kielce

\title{
ECONOMIC CRISES IN THE TWENTY-FIRST CENTURY AND THE IMPACT ON STATE SECURITY
}

The economic crises of the 21 st century have severely damaged the world economy. The first big crisis began in 2008 with the bankruptcy of one of the largest banks in the US, the Lehman Brothers Bank. The next crisis mainly affected Europe and was associated with the disclosure by the Greek government in 2009 of the dire state of public finances and huge monetary embezzlement. This crisis had a negative impact on many European countries belonging to the euro zone, as well as on many other countries outside this area, indirectly reducing investment or limiting international trade. Another crisis is related to the coronavirus pandemic announced at the beginning of 2020. At that time, most countries in the world have made a "lockdown" of the economy for many weeks. Various sectors of the economy were restricted or completely shut down almost overnight, seriously affecting societies.

Key words: economic crisis, economic security, security.

Introduction. The dynamic political and economic changes taking place in the world influence the shape of the security policy and the implemented measures adequate to the situation. Many countries today face serious threats. The aim of this study is to identify and analyze the impact of economic crises in the $21 \mathrm{st}$ century on the state of state security and how states respond to these crises. The aim is also to show the methods and instruments that minimize the effects of the crisis that the states have taken together and individually. The following research methods have been used in this study such as: the method of research and analysis of documents, observation and methods of analysis and criticism of the literature.

Contemporary states struggle with many threats. States have to deal with new, asymmetric threats: biological weapons, terrorism, uncontrolled illegal migration, drug trafficking, human trafficking. Some threats are related to the processes of globalization. Numerous political and economic conditions affect the security of individual states. What is the state security look like today? How does the 
Економічні науки: збірник наукових прачь Луиького національного технічного університету. Серія "Регіональна економіка". Випуск 17 (67). Редкол.: відп. ред. к.е.н., професор І.В. Кривов’язюк. Луцьк: ІВВ Луцького НТУ, 2020. 348 с.

economic crisis affect state security? Can we effectively combat economic threats? Do states cope better with economic crises by taking action and introducing instruments individually, or by applying a common policy, joint actions?

Economic conditions of security. The growing interdependence between states in the economic sphere allows us to conclude that economic conditions are becoming practically and in fact the most important in ensuring state security. The economic security of the state is characterized by the stabilization of the banking system, undisturbed operation of individual sectors of the national economy, or a strong and stable currency. Nowadays, it is a strong economy that determines the strength of the state. Any disruptions to the stability and economic order in a given country may lead to serious social and political problems. Threats to state security in the field of economic relations can be both military and non-military in nature.

The dimension of the state's economic security can be considered in the context of society development and the national economy itself, which affects the strength and position of the state in international economic relations. Economic conditions of state security are becoming more and more important. Building a strong position of the state is not related to maintaining a strong army or military involvement in armed conflicts, but a strong and stable economy becomes a condition. The sectoral approach to economic security is: energy, raw material, food, financial, technological, health security, etc.

The authors emphasize that the economic conditions of state security are influenced by the economic and defense potential of the state. Z. Kołodziejczak defines economic threats as "a set of factors of an external nature, the activation of which may lead to disturbances in the development of the defense and economic potential" [1]. The main economic threats that shape state security include excessive economic differences between states and regions, i.e. rich North and poor South. The economic and development disproportions of many countries pose threats to their stable and uninterrupted functioning. 
Економічні науки: збірник наукових прачь Луиького національного технічного університету. Серія "Регіональна економіка". Випуск 17 (67). Редкол.: відп. ред. к.е.н., професор І.В. Кривов'язюк. Луиьк: ІВВ Луцького НТУ, 2020. 348 с.

M. Leszczyńska points to the economic, sociological and political dimension of economic security on a micro and macro scale [2]. The factors related to security in macroeconomic terms include stability of employment, low unemployment, and predictable economic development prospects. In turn, the microeconomic approach mainly concerns the solvency and financial liquidity of enterprises or households, as well as the possibility of balancing the liabilities of these economic entities against the needs [2].

The economic security of the state is not only the condition of the national economy, the condition of public finances or the amount of internal and international debt. Nowadays, in the twenty-first century, more and more the sociological (social) aspect plays a key role in describing the state of economic security. The development of society influences the development of the entire economy, which is why we are talking about socio-economic development. The society perceives the state of security through the prism of individual assessment of the environment. The state must provide society with the best possible conditions for development, and then the individual can pursue his personal and professional goals with a sense of stability and social belonging. The lack of such conditions causes an increase in undesirable (pathological) human behavior, which reduces the overall state of security. Individuals are not eager to further self-development and raise their own social and professional qualifications, which affects the quality of the entire national economy. Many authors point out that the security and development of society are interrelated and interact. P. Dziekański points out that without security you cannot dream of development, and development facilitates ensuring security [3]. W.K. Senciagowa points out that economic security also means maintaining socio-political stability among the population [4].

Contemporary economic crises and state security. Shaping economic security in the European Union is a difficult and long-term process, overshadowed by the financial crisis of 2008 and its consequences, as well as the pandemic crisis caused by the SARSCOV-2 coronavirus of 2020. Both the former and the latter caused the economy serious and severe losses for each country. The latter, 
Економічні науки: збірник наукових прачь Луиького національного технічного університету. Серія "Регіональна економіка". Випуск 17 (67). Редкол.: відп. ред. к.е.н., професор І.В. Кривов'язюк. Луиьк: ІВВ Луцького НТУ, 2020. 348 с.

which began at the beginning of 2020, caused a "lockdown" of many areas of the economy of countries for many weeks in two phases (the first phase mainly the period from March to June 2020 and the second phase from October to December 2020).

There are many definitions of the economic crisis in the literature on the subject. This concept applies to a breakdown in the economic area, initiated by negative decisions of monetary institutions or the actions of speculators, as well as completely natural recessions, which should be associated with the emergence of business cycles, i.e. specific economic fluctuations, which are located in the frame from boom to bear and vice versa [5].

Chrabonszczewska connects the concept of the crisis with a sudden change, a breakdown that appeared on the financial market, which is related to the lack of liquidity and the inability to solvency of entities already operating on the market, forcing the competent state authorities to implement legal measures [6]. Nawrot defines a crisis as a turning point, a breakthrough or a breakdown of the current line of development, which was caused by the increasing state of tensions, as well as conflicts on the socio-economic level, which result, due to too late noticing and lack of appropriate reaction, breaking a certain development cycle [7].

The global economic crisis is a gradual event that affects the global economy. Its sources can be traced back to various factors, but it is generally initiated by:

a) Monetary policy that is non-perpetuating in the long term, performed by one or several central banks from among all developed countries (interest rates too low, ineffective investments, which may result in financial complications caused by overinvesting),

b) Initiating a crisis on many levels (in the banking sector, on the stock exchange, commodity exchange, in exchange rates),

c) A dynamic, negative shift in politics, including numerous mistakes in the economic sphere of states.

The economic crisis that began in the US in 2007, and which broke out in 2008 in connection with the bankruptcy of the big Lehman Brothers bank, had long-term consequences. The bank's bankruptcy was announced on September 15, 2008. In the 
Економічні науки: збірник наукових прачь Луиького національного технічного університету. Серія "Регіональна економіка". Випуск 17 (67). Редкол.: відп. ред. к.е.н., професор І.В. Кривов’язюк. Луцьк: ІВВ Луцького НТУ, 2020. 348 с.

2010 report, Anton R. Valukas identified the extensive use of accounting manipulations as the cause of the bank's failure [8]. However, many other factors pointed to the looming specter of a fall. These factors include: the inability to generate cash from operating activities, extensive and excessive capital investments, systematic use of external financing sources to cover the operating deficit, constant deterioration of cash flow in the three years immediately preceding the collapse. Regarding the latter factor, it is worth pointing out that the bank recorded negative net cash flows of 161.657 billion USD [9].

As a result of the Lehman Brothers crisis, not only was the US economy hit, but a huge number of countries on many continents were hit by the crisis. The US banking crisis has spread to other countries as in a communal vessel system. The crisis in Europe brought huge losses, as it had a significant impact on the economy of the Eurozone countries. The troubles of many countries, such as Greece, Spain or Portugal, were so serious that the situation threatened to collapse the zone, and perhaps even collapse the European Union that had been built for years.

In August 2007, problems appeared on the German banking market. The critical moment of economic problems in the EU, similarly to the USA, was 2009. At that time, practically the entire euro area fell into recession, and the individual states that had a common currency experienced negative economic growth, exceeded the limits of public debt and budgetary deficit [10]. Łasak emphasizes that the banking crisis quickly turned into a debt crisis. Even before the crisis, many euro area countries had high levels of debt. The assumptions adopted in the treaty on the establishment of the European Union of maintaining public debt at a level below $60 \%$ of GDP were not met not only by individual countries but also at the level of the entire euro area [11]. However, the financial crisis in Europe started with Greece, which for many years had been deceiving EU institutions and manipulating the presentation of financial statistics (creative accounting). In 2009, after the new government of G. Papandreou took power in Greece, it was announced that the budget deficit would be well above $12 \%$ of GDP 
Економічні науки: збірник наукових прачь Луиького національного технічного університету. Серія "Регіональна економіка". Випуск 17 (67). Редкол.: відп. ред. к.е.н., професор І.В. Кривов’язюк. Луцьк: ІВВ Луцького НТУ, 2020. 348 с.

instead of $6 \%$ of GDP [12]. Later it turned out that in 2009 the deficit amounted to $15.6 \%$ of GDP. It was necessary to act immediately. Not only the great states of the eurozone, i.e. Germany and France, also Great Britain (then part of the EU), and the International Monetary Fund rushed to help. Greece was granted aid in two stages: the first stage was in May 2010, during which 110 billion euros were transferred ( 80 billion euros from the largest euro area countries and 30 billion euros from the IMF). For the second time, Greece was granted aid in July 2011 in the amount of 130 billion EUR [13]. The condition for obtaining the second aid package was the implementation of effective social and economic reforms. These were very severe, even drastic cuts in public expenditure (including, among others: freezing wages in the public sector, reduction of incentive bonuses for performance of work and benefits, reduction of pensions, a VAT increase from $19 \%$ to $21 \%$ and an increase in excise duty for fuel, cigarettes, alcohol and luxury goods, cutting pensions and other social benefits, raising the retirement age) [14]. The rescue plans being introduced met with mass protests. However, saving Greece made sense for the entire European Union, as other countries also struggled with financial difficulties and the lack of response to the events in Greece could run into serious perturbations in other euro area countries. In 2015, it was decided to provide Greece with a third financial aid of $€ 33$ billion, also subject to further financial conditions. Aid for Greece ended in 2018 and in 8 years (2010-2018) it amounted to EUR 273 billion [15].

However, the financial crisis of 2008 was not the greatest, as it turned out from the perspective of the next decade. In 2020, the world had to face the largest economic crisis in history, caused by the SARC-COV-2 coronavirus. The pandemic announced by the World Health Organization (WHO) on March 11, 2020 resulted in the closure ("lock down") of almost entire national economies. Many sectors were closed or severely shut down for many weeks or even months to come [16]. The aviation, tourism and transport industries were painfully affected by this global decision by the WHO, as individual governments introduced an immediate, overnight ban on travel and the functioning of many sectors of the economy. 
Економічні науки: збірник наукових прачь Луиького національного технічного університету. Серія "Регіональна економіка". Випуск 17 (67). Редкол.: відп. ред. к.е.н., професор І.В. Кривов'язюк. Луиьк: ІВВ Луцького НТУ, 2020. 348 с.

Numerous restrictions imposed by almost all countries in the world have led to the bankruptcy of many enterprises, and rebuilding the current level of economies will certainly take many years to come.

The world is constantly changing, and it's hard to predict what will happen in the next few months, let alone a few years away. As it turned out, the 2020 coronavirus pandemic crisis effectively stopped or severely limited all development plans. Nobody, both the state and the society, was prepared for such an event. Also, it is difficult to predict how long the ongoing armed and political conflicts will last. It is also difficult to talk about economic stability these days, as the example of a sudden closure of economies in 2020 due to the coronavirus contradicts such theses. The escalation of the conflict in Donbass in Ukraine or the dispute over Crimea will for a long time indicate that political or economic security in this region is a distant prospect.

Summary. Every economic crisis has huge consequences for every society. It has a negative impact on the perception of security by the society, as it causes a number of negative social consequences, e.g. job loss, increased unemployment, increased inflation, and restrictions on imports and exports. Much depends on the policy of the state, how the state will counteract the negative effects and how it will deal with the management of the resulting crisis. The state has a number of instruments that it can use in the fight against the crisis. Much depends on the skillful conduct of politics and the implementation of appropriate economic, legal and organizational solutions.

Each crisis brings with it new threats that are its consequences. Often they reveal hidden imperfections of the state policy or the functioning of the entire economy. The conditions of state security are multilayered. Economic and political conditions cannot be separated. They are interrelated. International relations and interdependencies are important in ensuring state security. It is on alliances and agreements that the individual security of each state is based on. Political and economic stabilization are highly desirable in today's world, as they condition the development and civilization and technical progress of the state. The current policy of the state should 
Економічні науки: збірник наукових прачь Луиького національного технічного університету. Серія "Регіональна економіка". Випуск 17 (67). Редкол.: відп. ред. к.е.н., професор І.В. Кривов’язюк. Луцьк: ІВВ Луцького НТУ, 2020. 348 с.

take into account internal and external conditions, as more and more threats to state security are of a cross-border nature.

It can be pointed out that the Ukrainian-Russian political conflict has far-reaching economic consequences not only for these two countries, but also for many others who have trade relations with these countries. Both Ukraine and Russia feel the severe economic effects of the political crisis that has been ongoing since 2014 . Despite huge money transfers from international financial institutions to help Ukraine, the country's economic situation is still far from favorable.

The economic crisis of 2020 caused by the coronavirus pandemic and the ongoing political crises in Europe, such as the Russian-Ukrainian over Crimea or Donbas, as well as extensive demonstrations and protests of the opposition in Belarus in 2020 after the presidential election, in which the current president A. Lukashenka once again won, pose a great challenge to the internal security of European countries. Political and economic threats can only be counteracted with joint and several measures. Today's economic crises are not easy to solve, as they are cross-border and multi-dimensional, and individual approach is not conducive to increasing security. States must act together in an organized manner to develop economies and entire societies. Socio-economic development contributes to strengthening the sense of security both in the internal perspective and in the perception of the international community.

\section{Список бібліографічного опису}

1.Michałowski S., Bezpieczeństwo ekonomiczne w stosunkach wschódzachód, Warsaw 1990, p. 23.

2.Leszczyńska M., Bezpieczeństwo ekonomiczne państwa a rozwój gospodarki i społeczeństwa, in: „Nierówności Społeczne a Wzrost Gospodarczy”, No 56 (4/2018), p. 290.

3.Dziekański P., Bezpieczeństwo ekonomiczne wyzwaniem wspótczesnego regionu - próba oceny syntetycznej, in: „Kultura Bezpieczeństwa. Nauka-PraktykaRefleksje", No 16/2014, p. 125.

4.Księżopolski M., Bezpieczeństwo ekonomiczne, Dom Wydawniczy ELIPSA, Warsaw 2011, p. 239.

5.Filar D., Rzońca A., Wójtowicz G., Ekonomia po polsku, Warsaw 2007, pp. 239-240. 
Економічні науки: збірник наукових прачь Луиького національного технічного університету. Серія "Регіональна економіка". Випуск 17 (67). Редкол.: відп. ред. к.е.н., професор І.В. Кривов’язюк. Луцьк: ІВВ Луцького НТУ, 2020. 348 с.

6.Chrabonszczewska W., Międzynarodowe organizacje finansowe, Warsaw 2005 , p. 315.

7.Nawrot W., Globalny kryzys finansowy XXI wieku. Przyczyny, przebieg, skutki, prognozy, Warsaw 2009, p. 10.

8. Azadinamin A., The Bankruptcy of Lehman Brothers: Causes of Failure \& Recommendations Going Forward, Social Science Research, 2013, p. 6.

9. Ibidem, p. 11. See: Mensah Mawutor J.K., The Failure of Lehman Brothers: Causes, Preventive Measuresand Recommendations, in: "Research Journal of Finance and Accounting", Vol.5, No.4, 2014, pp. 85-91.

10. Roubini N., Mihm S., Ekonomia kryzysu, Warsaw 2011, p. 55.

11. Łasak P., Wewnętrzne i zewnętrzne uwarunkowania kryzysu w Grecji, in: „Studia Prawno-ekonomiczne”, Vol. CII, 2017, p. 201.

12. Sporek T., Globalne konsekwencje kryzysu finansowego w Grecji, in: „Studia ekonomiczne”, Katowice 2013, p. 23.

13. Łasak P., op.cit., p. 207.

14. Górniewicz G., Kryzys finansów publicznych Grecji, in: Studia z zakresu prawa, administracji i zarządzania UKW, Vol. 6, 2014, p. 39.

15. Maurice E., Greece and creditors proclaim 'end of crisis', EUObserver, 22.06.2018, https://euobserver.com/economic/142165 (access: 10.092.2020).

16. Nicola M. (et al.)., The socio-economic implications of the coronavirus pandemic (COVID-19): A 17 review, https://www.ncbi.nlm.nih.gov/pmc/articles/PMC7162753/, access: 2.09.2020. 